\title{
Aprepitant: the evidence for its place in the prevention of chemotherapy-induced nausea and vomiting
}

\author{
Paul Chrisp
}

Core Medical Publishing, Knutsford, UK

\begin{abstract}
Introduction: Chemotherapy-induced nausea and vomiting (CINV) represents a significant burden on patients and healthcare systems. Despite the introduction of serotonin antagonists, many patients still experience CINV, particularly delayed symptoms occurring more than 24 hours after chemotherapy. Aprepitant is a selective neurokinin-1 $\left(\mathrm{NK}_{1}\right)$ receptor antagonist approved for use with other antiemetics to prevent CINV caused by moderately to highly emetogenic chemotherapy.
\end{abstract}

Aims: To review the evidence underlying the use of aprepitant to prevent CINV.

Evidence review: In patients receiving moderately and highly emetogenic chemotherapy, adding aprepitant to standard antiemetic therapy with dexamethasone and a serotonin antagonist significantly improved control of CINV. The degree of control of delayed CINV was particularly pronounced, and effectiveness was more likely to be maintained in multiple cycles compared with standard therapy. Nausea was generally less frequent among patients taking aprepitant. More patients receiving aprepitant were satisfied with their treatment and reported minimal/no impact of CINV on daily activities. Aprepitant appears to be well tolerated, with fatigue being the most commonly reported adverse event. The drug is an inhibitor and inducer of cytochrome P450 (CYP) 3A4, resulting in contraindications and caution with some concomitant medication. Limited economic evidence suggests that a proportion of the acquisition cost of aprepitant may be offset by savings in overall direct costs of managing CINV.

Place in therapy: The evidence supports the recommended use of aprepitant in clinical guidelines for the prevention of CINV due to highly emetogenic chemotherapy, and its recently approved role in regimens with moderate risk. It is particularly useful for delayed symptoms.

Key words: aprepitant, chemotherapy, evidence, nausea, vomiting

\section{Core evidence place in therapy summary for aprepitant in the prevention of chemotherapy-induced nausea and vomiting}

\begin{tabular}{|c|c|c|}
\hline Outcome measure & Evidence & Implications \\
\hline \multicolumn{3}{|c|}{ Patient-oriented evidence } \\
\hline $\begin{array}{l}\text { Control of acute and } \\
\text { delayed emesis }\end{array}$ & Clear & $\begin{array}{l}\text { Adding aprepitant to standard antiemetic therapy with dexamethasone plus a serotonin antagonist improves } \\
\text { control of emesis and reduces need for rescue medication in patients receiving moderately or highly } \\
\text { emetogenic chemotherapy }\end{array}$ \\
\hline Control of nausea & Clear & $\begin{array}{l}\text { Adding aprepitant to standard antiemetic therapy with dexamethasone plus a serotonin antagonist reduces } \\
\text { symptoms of nausea in patients receiving moderately or highly emetogenic chemotherapy }\end{array}$ \\
\hline Patient satisfaction & Clear & $\begin{array}{l}\text { Patients more satisfied with their antiemetic therapy when aprepitant added; less impact of symptoms on } \\
\text { daily activities }\end{array}$ \\
\hline \multicolumn{3}{|l|}{ Economic evidence } \\
\hline Cost effectiveness & Limited & Acquisition cost of aprepitant may be partially offset by savings in overall direct costs \\
\hline
\end{tabular}




\section{Scope, aims, and objectives}

Aprepitant (Emend ${ }^{\circledR}$, Merck) is a selective neurokinin-1 ( $\mathrm{NK}_{1}$; substance $\mathrm{P}$ ) receptor antagonist, which was approved by the Food and Drug Administration (FDA) for use with other antiemetics in the prevention of nausea and vomiting in patients with cancer receiving moderately or highly emetogenic chemotherapy in October 2005 and in March 2003, respectively. Aprepitant is believed to prevent emesis by blocking the binding of substance $\mathrm{P}$ to $\mathrm{NK}_{1}$ receptors in the brain.

This article reviews the evidence for the place of aprepitant in the prevention of the acute and delayed chemotherapy-induced nausea and vomiting (CINV).

\section{Methods}

English language literature searches were conducted on June 30, 2006 in the following databases, searching from the beginning of the database to date unless otherwise stated. The search strategy was "aprepitant AND (nausea AND vomiting)" unless otherwise stated:

- PubMed, http://www.ncbi.nlm.nih.gov/entrez/query.fcgi, 1966 to date. Limits imposed "English," "clinical trial," "meta analysis," "randomized controlled trial," "review," "human," for specificity

- EMBASE, http://www.datastarweb.com, 1974 to date. Search term "(aprepitant AND nausea and vomiting AND chemotherapy) AND (LG=EN) AND ((clinical-trial\#))"

- BIOSIS, http://www.datastarweb.com. Search term "(aprepitant AND nausea and vomiting AND chemotherapy) AND (LG=EN) AND (PT=MEETING-ABSTRACT)"

- Database of Abstracts of Reviews of Effects (DARE), National Health Service (NHS) Economic Evaluations Database (NHSEED), Health Technology Assessment (HTA), http://www.york.ac.uk/inst/crd/crddatabases.htm. All three databases searched together. All fields searched

- NHS HTA, http://www.ncchta.org

- National Guideline Clearinghouse, http://www.guideline.gov

- National Institute for Health and Clinical Excellence (NICE), http://www.nice.org.uk

- Cochrane Database of Systematic Reviews (CDSR), http://www.cochrane.org/index0.htm. Entire site searched

- Clinical Evidence (BMJ), http://www.clinicalevidence.com

- Clinical trials databases, http://www.clinicaltrials.gov, and http://www.clinicalstudyresults.org

Online abstracts from the following congresses were searched using the search strategy terms "aprepitant" or "Emend":
- American Society of Clinical Oncology (ASCO), all conferences from 2000 to 2006, http://www.asco.org

- European Society for Medical Oncology (ESMO), all conferences from 2002 to 2005, http://www.esmo.org

Following hand searching and removal of articles unrelated to CINV, duplicates, nonsystematic reviews, editorials, records of study methodology, and pharmacokinetic studies, a total of 15 full papers and six abstracts were included in the evidence base (Table 1).

\section{Disease overview}

Nausea and vomiting are among the most feared side effects of cancer chemotherapy, with good reason. CINV can cause dehydration, malnutrition, interrupt critical chemotherapy, and significantly impair daily activities and quality of life. Electrolyte imbalances causing muscle cramps, hypotension, and vital organ damage can result from severe or prolonged CINV (Bender et al. 2002), as can fatigue and confusion. Occasionally, esophageal tears are caused by frequent vomiting, and pneumonia results from aspiration of vomit (Bender et al. 2002). Poor control of CINV can also increase healthcare costs (Stewart et al. 1999).

Many factors influence the incidence of CINV. The emetogenic potential of different drugs used in chemotherapy varies considerably (Table 2), with cisplatin at doses higher than $50 \mathrm{mg} / \mathrm{m}^{2}$ causing emesis in almost all patients (Aguilar et al. 2005).

Patient characteristics also determine the likelihood of CINV, with emesis occurring more frequently in younger patients, women, and those with a history of motion sickness, and less likely in patients with a history of alcohol abuse (Markman 2002).

Table 1 | Evidence base included in the review

\begin{tabular}{|lcc|}
\hline Category & \multicolumn{2}{c|}{ Number of records } \\
\cline { 2 - 3 } & Full papers & Abstracts \\
\hline Initial search & 121 & 26 \\
records excluded & 107 & 21 \\
records included & 14 & 5 \\
Additional studies identified & 1 & 1 \\
Total records included & 15 & 6 \\
Level 1 clinical evidence & 1 & 1 \\
(systematic review, meta analysis) & 13 & 1 \\
Level 2 clinical evidence (RCT) & & 3 \\
Level $\geq 3$ clinical evidence & 0 & 0 \\
trials other than RCT & 1 & 1 \\
case reports & 0 & \\
Economic evidence & & \\
\hline For definitions of levels of evidence, see Editorial Information on inside back cover. & & \\
RCT, randomized controlled trial. & 15 & \\
\hline
\end{tabular}


Table 2 | Emetogenic potential of chemotherapeutic agents [adapted from Herrstedt J, et al. ESMO minimum clinical recommendations for prophylaxis of chemotherapy-induced nausea and vomiting (NV). Ann Oncol. 2005;16(Suppl. 1):i77-i79, by permission of Oxford University Press]

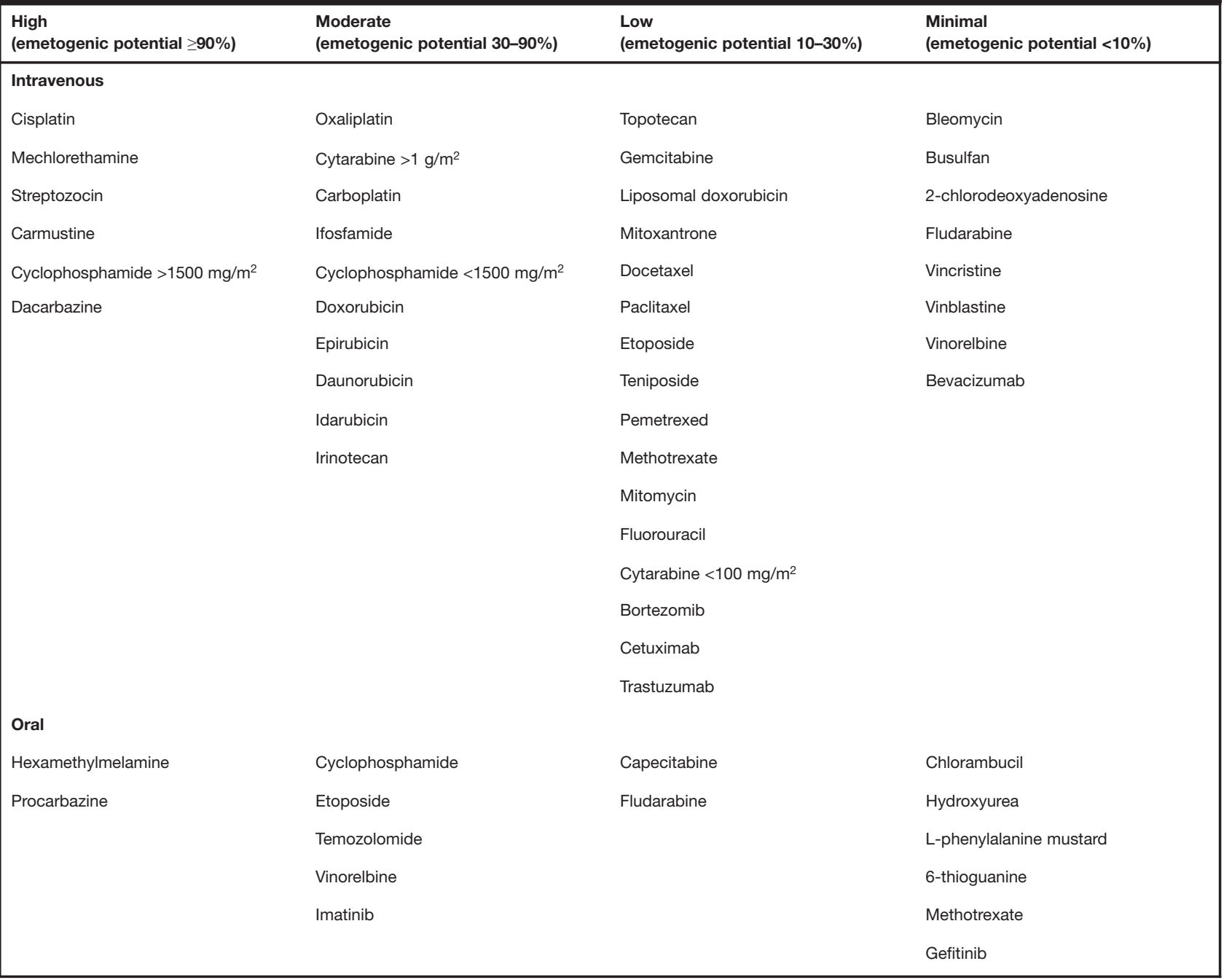

There are three types of CINV: acute (within 24 hours after the start of chemotherapy, persisting for a number of hours); delayed (more than 24 hours after the end of chemotherapy, may persist for days); and anticipatory (before chemotherapy is given, based on prior experience). Acute CINV is generally assumed to present within 1 or 2 hours, although agents such as cyclophosphamide and carboplatin are often associated with emesis after 8-10 hours (Markman 2002), and the emetic response to cisplatin is most frequent and severe within 4-8 hours of administration (Aguilar et al. 2005). Delayed CINV is perhaps more distressing and burdensome than acute symptoms, because the incidence is higher, it can last longer, and it is more likely to occur when the patient is at home following chemotherapy (Markman 2002; Aguilar et al. 2005). Delayed symptoms have been reported in approximately $40 \%$ of patients who experience no acute CINV (Aguilar et al. 2005). Furthermore, awareness of the extent of delayed CINV is often underestimated by healthcare professionals (Aguilar et al. 2005). Delayed CINV is most common with cisplatin at doses $>100 \mathrm{mg} / \mathrm{m}^{2}$ [in $60-89 \%$ of patients (Gralla et al. 1999; Aguilar et al. 2005)], followed by carboplatin, cyclophosphamide, and doxorubicin [in 20 to $30 \%$ of patients (Gralla et al. 1999; Markman 2002)]. Anticipatory CINV is more likely in patients who have experienced emesis earlier in their chemotherapy; up to $30 \%$ of such patients still have anticipatory symptoms in the fourth cycle of treatment (Aguilar et al. 2005).

The emetic process is complex, involving many central and peripheral neuroreceptors and neurotransmitters including dopamine, serotonin, and substance P. Ultimately, noxious stimuli influence the vomiting center in the lateral reticular formation of the brain, causing emesis. Although the precise mechanism of CINV is not fully understood, it is now believed that acute emesis is caused by peripheral serotonergic pathways, and delayed 
symptoms by centrally acting substance $\mathrm{P}$ acting on $\mathrm{NK}_{1}$ receptors (Fig. 1). Anticipatory CINV is caused by the patient forming a psychologic association between chemotherapy and nausea and vomiting, and is therefore difficult to control if previous treatment has resulted in CINV.

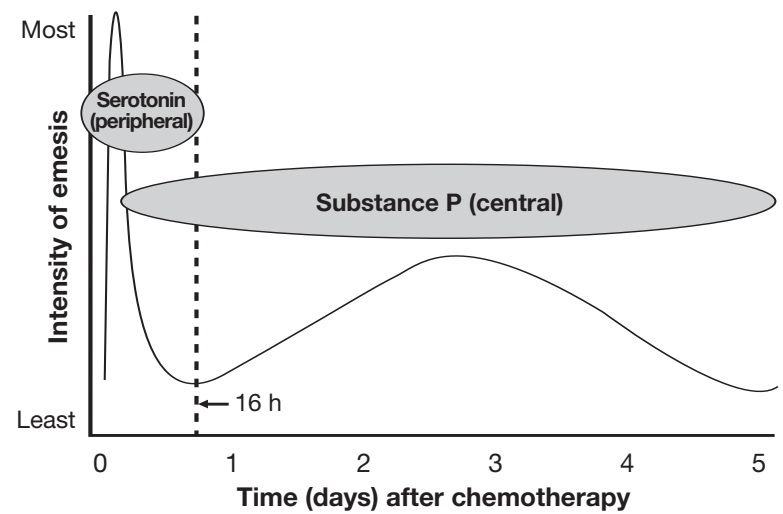

Fig. 1 | Proposed mechanism and time course of chemotherapyinduced nausea and vomiting with cisplatin [adapted from Expert Rev Anticancer Ther. 5(6), 963-972 (2005) with permission of Future Drugs, Ltd]

\section{Current therapy options}

The multifactorial nature of CINV makes it difficult to control, therefore prevention is more effective than treatment. Management is centered on prevention of acute emesis, which in turn significantly reduces the incidence and severity of delayed and anticipatory emesis (Gralla et al. 1999; Markman 2002). Preventive therapy is based on a combination of agents that affect the different pathophysiologic pathways underlying acute and delayed emesis.

Several classes of antiemetic drugs are available, including serotonin receptor antagonists (e.g. dolasetron, granisetron, ondansetron, and palonosetron), corticosteroids (principally dexamethasone), dopamine antagonists (e.g. metoclopramide, prochlorperazine), and the $\mathrm{NK}_{1}$ receptor antagonist aprepitant.

Several evidence-based clinical practice guidelines are available and are in broad agreement (Table 3). Serotonin antagonists and corticosteroids have been the standard of care in the guidelines, and the combination is effective in between 60 and $70 \%$ of patients experiencing acute CINV (Viale 2005). Corticosteroids alone are effective in up to $90 \%$ of patients receiving low or moderately emetogenic chemotherapy (Markman 2002). Both classes of drug are well tolerated, with headache and constipation most often associated with serotonin antagonists, and sleep disturbances with corticosteroids (Markman 2002; Aguilar et al. 2005; Viale 2005).

Metoclopramide remains a treatment option in the National Comprehensive Cancer Network (NCCN) guidelines for delayed CINV with moderately emetogenic chemotherapy and acute CINV with low-risk chemotherapy, with prochlorperazine as an alternative in the latter scenario. These guidelines also recommend that diphenhydramine can be given with a dopamine antagonist, to counter the potential for distressing extrapyramidal adverse effects and sedation (Viale 2005). Dopamine antagonists, which have long been the treatment of choice for CINV, are being superseded by the newer more effective and better-tolerated agents, and it has been recommended that their use should be reserved for patients who fail to respond to serotonin antagonists (Markman 2002).

\section{Unmet needs}

Acute CINV is still experienced by up to $40 \%$ of patients receiving a serotonin antagonist plus dexamethasone before highly emetogenic cisplatin chemotherapy (Gralla et al. 1999; Markman 2002; Viale 2005), and $15 \%$ of those receiving a noncisplatinbased high-risk regimen (Gralla et al. 1999). The observation that serotonin antagonists are less effective in preventing delayed CINV led to the proposed pathophysiology (see Fig. 1). Between 44 and $53 \%$ of patients receiving highly emetogenic chemotherapy with cisplatin $\geq 70 \mathrm{mg} / \mathrm{m}^{2}$ and preventive treatment with a serotonin antagonist plus dexamethasone experienced delayed CINV (Aguilar et al. 2005). There is also evidence that the protective effect of a serotonin antagonist plus a corticosteroid wears off during multiple cycles of chemotherapy (Soukop et al. 1992; Sigsgaard et al. 1999, 2001).

With moderately emetogenic chemotherapy, acute CINV can be prevented in up to $90 \%$ of patients receiving a corticosteroid, which also reduces the risk of delayed emesis (Gralla et al. 1999). However, some chemotherapy of moderate emetogenic potential has a greater tendency to cause delayed CINV, notably carboplatin, cyclophosphamide, and doxorubicin (Gralla et al. 1999; Markman 2002). Furthermore, although cyclophosphamide and doxorubicin individually are classified as being moderately emetogenic, the likelihood of CINV increases when these agents are combined, as they frequently are in the adjuvant treatment of women with breast cancer (Grunberg et al. 2005). As mentioned earlier, particular patient groups, such as women, are at higher risk of CINV. The choice of preventive treatment for CINV is dependent on the emetogenic potential of the chemotherapy and the individual patient characteristics. There remains a need to improve the management of CINV, particularly delayed symptoms in response to multiple cycles of moderately emetogenic chemotherapy in susceptible patients. A greater recognition of CINV (particularly delayed symptoms) among healthcare professionals, a realization that it can be effectively managed, and improved compliance with clinical practice guidelines, which is often poor (Mertens et al. 2003), are also factors that need to be considered.

\section{Rationale for aprepitant}

Aprepitant was approved by the FDA in March 2003 for the prevention of acute and delayed CINV with highly emetogenic chemotherapy, and in October 2005 for use with moderately emetogenic regimens. It is the first of a new class of agents, the $\mathrm{NK}_{1}$ receptor antagonists, to be clinically available. Aprepitant is thought to prevent emesis by blocking the binding of substance $P$ to $\mathrm{NK}_{1}$ receptors in the brain (Aguilar et al. 2005; Kris et al. 2005; 
Table 3 | Evidence-based clinical practice guidelines for the prevention of acute and delayed chemotherapy-induced nausea and vomiting

\begin{tabular}{|c|c|c|c|}
\hline Guideline & Emetogenic potential & Acute CINV & Delayed CINV \\
\hline \multirow[t]{5}{*}{ ASCO (Kris et al. 2006) } & High & $\begin{array}{l}\text { Serotonin antagonist }+ \text { dexamethasone }+ \text { aprepitant } \\
\text { before chemotherapy }\end{array}$ & Dexamethasone + aprepitant \\
\hline & $\begin{array}{l}\text { Moderate: patients } \\
\text { receiving anthracycline + } \\
\text { cyclophsophamide }\end{array}$ & $\begin{array}{l}\text { Aprepitant }+ \text { serotonin antagonist }+ \text { dexamethasone } \\
\text { before chemotherapy }\end{array}$ & Aprepitant \\
\hline & Moderate & Serotonin antagonist + dexamethasone & $\begin{array}{l}\text { Serotonin antagonist or } \\
\text { dexamethasone }\end{array}$ \\
\hline & Low & Dexamethasone & No routine antiemetic \\
\hline & Minimal & No routine antiemetic & No routine antiemetic \\
\hline \multirow[t]{4}{*}{ ESMO (Herrstedt et al. 2005) } & High & Serotonin antagonist + corticosteroid + aprepitant & Corticosteroid + aprepitant \\
\hline & Moderate & Serotonin antagonist + corticosteroid & $\begin{array}{l}\text { Serotonin antagonist or } \\
\text { corticosteroid }\end{array}$ \\
\hline & Low & Single agent e.g. corticosteroid & No routine antiemetic \\
\hline & Minimal & No routine antiemetic & No routine antiemetic \\
\hline \multirow[t]{5}{*}{$\begin{array}{l}\text { MASCC (Kris et al. 2005; } \\
\text { MASCC 2005) }\end{array}$} & High & $\begin{array}{l}\text { Serotonin antagonist + dexamethasone + aprepitant } \\
\text { before chemotherapy }\end{array}$ & Dexamethasone + aprepitant \\
\hline & $\begin{array}{l}\text { Moderate: patients } \\
\text { receiving anthracycline + } \\
\text { cyclophsophamide }\end{array}$ & $\begin{array}{l}\text { Serotonin antagonist + dexamethasone }+ \text { aprepitant } \\
\text { before chemotherapy (women specifically) }\end{array}$ & Dexamethasone or aprepitant \\
\hline & Moderate & $\begin{array}{l}\text { Serotonin } \\
\text { antagonist + dexamethasone in first course }\end{array}$ & $\begin{array}{l}\text { Dexamethasone or serotonin } \\
\text { antagonist }\end{array}$ \\
\hline & Low & Single agent e.g. corticosteroid & None stated \\
\hline & Minimal & No routine antiemetic & None stated \\
\hline \multirow[t]{4}{*}{ NCCN (NCCN 2006) } & High & $\begin{array}{l}\text { Aprepitant }+ \text { serotonin antagonist }+ \text { dexamethasone } \pm \\
\text { lorazepam before chemotherapy }\end{array}$ & $\begin{array}{l}\text { Aprepitant }+ \text { dexamethasone } \pm \\
\text { lorazepam before chemotherapy }\end{array}$ \\
\hline & $\begin{array}{l}\text { Moderate: patients } \\
\text { receiving anthracycline + } \\
\text { cyclophsophamide; select patients } \\
\text { receiving cisplatin, carboplatin, } \\
\text { doxorubicin, epirubicin, ifosfamide, } \\
\text { irinotecan, methotrexate }\end{array}$ & $\begin{array}{l}\text { Aprepitant }+ \text { serotonin antagonist }+ \text { dexamethasone } \\
\text { before chemotherapy }\end{array}$ & $\begin{array}{l}\text { Aprepitant }+ \\
\text { dexamethasone } \pm \text { lorazepam }\end{array}$ \\
\hline & Moderate & Serotonin antagonist + dexamethasone \pm lorazepam & $\begin{array}{l}\text { Dexamethasone or } \\
\text { serotonin antagonist or } \\
\text { metoclopramide } \pm \\
\text { diphenhydramine }\end{array}$ \\
\hline & Low & \multicolumn{2}{|c|}{ Dexamethasone or prochlorperazine or metoclopramide \pm diphenhydramine \pm lorazepam } \\
\hline
\end{tabular}

Viale 2005). By acting on another neuroreceptor implicated in CINV rather than serotonin receptors, it therefore offers another option for the management of this multifactorial condition.

\section{Clinical evidence with aprepitant}

In the study of drugs that prevent CINV a number of endpoints are used. These include control rates based on the number of vomiting episodes (complete control=no emesis), use of rescue antiemetic therapy, and the more subjective patient perceptions of nausea measured by visual analog scale (VAS, with $0=$ no nausea and $100=a s$ bad as possible) and effect on quality of life (QOL) using the Functional Living Index Emesis (FLIE) questionnaire. Some investigators use combined secondary endpoints including no vomiting, no rescue therapy, and no significant nausea (VAS score <25) (complete protection), and no vomiting, no rescue therapy, and no nausea (VAS score $<5$ ) (total control). The evidence for the effectiveness of aprepitant in controlling vomiting is primarily evaluated below using complete response rates (no emesis and no rescue medication) as this was the most frequently studied endpoint. Efficacy was assessed for acute and delayed CINV. 
Thirteen randomized controlled trials (RCTs) published in full were identified from the literature search, four of which were subanalyses of pooled data from earlier studies (de Wit et al. 2004; Gralla et al. 2005; Warr et al. 2005a; Hesketh et al. 2006a). Two of the earlier trials (Campos et al. 2001; Van Belle et al. 2002) have been criticized for using substandard antiemetic prophylaxis, defined as patients not receiving a serotonin antagonist plus a corticosteroid on the day of chemotherapy administration for acute CINV, and either treatment other than a corticosteroid or unspecified antiemetic treatment for delayed CINV (Holdsworth \& Vo-Nguyen 2005). However, at the time these trials were conducted (1997 to 1998), there was no consensus on standard antiemetic prophylaxis, which may explain the discrepancy (Van Belle et al. 2002). Two papers reported a trial investigating the efficacy of aprepitant after one (Warr et al. 2005b) or multiple (Herrstedt et al. 2005b) cycles of moderately emetogenic chemotherapy. For all studies, modified intention to treat (mITT) was used for efficacy analysis, defined as patients who received chemotherapy, study drug, and had at least one posttreatment assessment during a cycle.

Two systematic reviews were identified in the literature. A health technology assessment of the limited evidence available in 2003 concluded that aprepitant appeared to offer a significant advantage when added to standard antiemetic therapy with a serotonin antagonist and a corticosteroid during highly emetogenic chemotherapy (CCOHTA 2003). A meta analysis of seven RCTs published between 1990 and 2003 on unspecified $\mathrm{NK}_{1}$ receptor antagonists used with cisplatin 50 to $100 \mathrm{mg} / \mathrm{m}^{2}$ revealed a significant increase in complete responses to delayed CINV, with no significant effect in the acute phase (Tremont-Lukats et al. 2004).

While these systematic reviews represent level 1 evidence, they have been superseded by full publication of level 2 evidence on the efficacy of aprepitant, which is considered below.

\section{Control of CINV with highly emetogenic chemotherapy}

There is strong evidence for the efficacy of aprepitant in combination with other antiemetics for the prevention of nausea and vomiting caused by highly emetogenic chemotherapy with cisplatin $\geq 70 \mathrm{mg} / \mathrm{m}^{2}$ (Table 4 ).

One of the first trials demonstrated that the addition of aprepitant $400 \mathrm{mg}$ on day 1 of chemotherapy significantly reduced the frequency of both acute and delayed emesis compared with a standard regimen of granisetron and dexamethasone (Campos et al. 2001). This triple combination was also significantly more effective than aprepitant plus dexamethasone alone for delayed emesis, but not acute symptoms. Nausea control was similarly better for the combination of aprepitant, granisetron, and dexamethasone during acute and delayed phases. Nevertheless, the combination of aprepitant plus dexamethasone, without granisetron, provided some degree of protection against acute and delayed CINV; administering a further dose of aprepitant the night before chemotherapy conferred no additional benefit (Table 4).
The efficacy of the dual combination of aprepitant plus dexamethasone was confirmed by Van Belle et al. (2002). Significantly more patients receiving the combination of intravenous L-758,298 (the prodrug of aprepitant) plus dexamethasone on day 1 followed by oral aprepitant on days 2 to 5 after chemotherapy achieved a complete response in the delayed phase compared with patients receiving ondansetron plus dexamethasone (Table 4). However, the converse was true for the acute phase, with this combination being more effective in controlling acute nausea and therefore having higher patient satisfaction ratings (Table 5). Control of nausea symptoms in the delayed phase was not significantly different among the three groups.

These trials used doses of aprepitant $400 \mathrm{mg}$ or L-758,298 $100 \mathrm{mg}$ on day 1 , and aprepitant $300 \mathrm{mg}$ on days 2 to 5 . A subsequent study investigated the efficacy of aprepitant 375 or $125 \mathrm{mg}$ on day 1 and 250 or $80 \mathrm{mg}$ on days 2 to 5 added to standard therapy with ondansetron $32 \mathrm{mg}$ plus dexamethasone $20 \mathrm{mg}$ on day 1 and dexamethasone $8 \mathrm{mg}$ on days 2 to 5 during single (Chawla et al. 2003) or multiple (de Wit et al. 2003) cycles of highly emetogenic chemotherapy. However during this trial a pharmacokinetic interaction became apparent, with aprepitant resulting in an approximately two-fold increase in dexamethasone plasma levels in healthy volunteers (Blum et al. 2003) (see Dosage, administration, and formulations). The higher doses of aprepitant were therefore discontinued. Adding aprepitant $125 \mathrm{mg}$ on day 1 followed by $80 \mathrm{mg}$ on days 2 to 5 to a standard regimen of ondansetron plus dexamethasone resulted in significantly improved rates of acute and delayed emesis control, with complete response in 83 and $73 \%$ of patients, respectively (Chawla et al. 2003). Control was also improved with a lower dose regimen of aprepitant $40 \mathrm{mg}$ on day 1 and $25 \mathrm{mg}$ on days 2 to 5 , but only reached a significant difference from standard therapy during the delayed phase (Table 4). The efficacy of aprepitant $125 \mathrm{mg}$ (day 1) and $80 \mathrm{mg}$ (days 2-5) was sustained during six cycles of chemotherapy (de Wit et al. 2003). A complete response was achieved in $64 \%$ of patients in cycle 1 and $59 \%$ in cycle 6 , compared with the significantly lower rates of 49 and $34 \%$, respectively, in patients receiving standard antiemetic therapy (Table 4).

These early phase II studies therefore provided evidence of the efficacy of aprepitant added to standard antiemetic therapy given during highly emetogenic cisplatin-based chemotherapy. However, the dose of dexamethasone was not adjusted to compensate for the elevation in levels caused by aprepitant, optimal dosages of aprepitant were still being defined, and administration of the drug for 5 days after chemotherapy did not seem to provide any further clinical benefit. Two phase III randomized, double-blind, parallelgroup studies were therefore designed to investigate the efficacy of aprepitant at a dosage of $125 \mathrm{mg}$ on day 1 and $80 \mathrm{mg}$ on days 2 to 3 , with a concomitant downward adjustment of dexamethasone dose to equate plasma levels between patients receiving standard antiemetic therapy and those receiving additional aprepitant (Hesketh et al. 2003; Poli-Bigelli et al. 2003). 
Table 4 | Level 2 evidence of outcomes achieved with aprepitant in the prevention of CINV due to highly emetogenic chemotherapy in double-blind, multicenter, parallel-group RCTs (all $P$ values vs standard therapy without aprepitant unless otherwise stated)

Chemotherapy Antiemetic treatment

Outcome

Reference

regimen

\begin{tabular}{ll}
\hline \multicolumn{2}{c}{ Acute phase } \\
\hline Complete & Nausea (median \\
response & VAS scores; \\
$(\%)^{\mathrm{a}}$ & $0=$ none; \\
& $100=$ worst)
\end{tabular}

\begin{tabular}{ll}
\multicolumn{2}{c}{ Delayed phase } \\
\hline Complete & Nausea (median \\
response & VAS scores; \\
$(\%)^{\mathrm{a}}$ & $0=$ none; \\
& $100=$ worst)
\end{tabular}

Cis-based Day 1: Gra $10 \mathrm{mcg} / \mathrm{kg}+$ Dex $20 \mathrm{mg}+$ Ap $400 \mathrm{mg} 77$

0

$52(P<0.001) \quad 1(P=0.003)$

Navari et al. 1999

$\geq 70 \mathrm{mg} / \mathrm{m}^{2}$, Day 2-5: Ap $300 \mathrm{mg}$

1 cycle $\quad(n=54)$

Day 1: Gra $10 \mathrm{mcg} / \mathrm{kg}$ + Dex $20 \mathrm{mg}+\operatorname{Ap} 400 \mathrm{mg} 83$

$83 \quad 0$

$0 \quad 43(P=0.003) \quad 3$

Day 2-5: Pla

$(n=54)$

Day 1: Gra $10 \mathrm{mcg} / \mathrm{kg}$ + Dex $20 \mathrm{mg}+\mathrm{Pla}$

Day 2-5: Pla

$57(P=0.004$

vs other two

groups

combined)

Cis-based $(\mathrm{n}=51)$

51

7.5

16

10

$\geq 70 \mathrm{mg} / \mathrm{m}^{2}$, Day 1: Gra $10 \mathrm{mcg} / \mathrm{kg}+$ Dex $20 \mathrm{mg}+$ Pla

Day 2-5: Pla

$(n=90)$

Day -1: Pla

$75(P<0.01) \quad 1(P<0.05)$

$41(P<0.05)$

$2(P<0.05)$

Day 1: Gra 10 mcg/kg + Dex 20 mg + Ap 400 mg

Day 2-5: Ap $300 \mathrm{mg}$

$(\mathrm{n}=86)$

Day -1: Ap 400 mg

44

8.5

$39(P<0.05) \quad 3(P<0.05)$

Day 1: Dex 20 mg + Ap 400 mg + Pla

Day 2-5: Ap $300 \mathrm{mg}$

$(\mathrm{n}=89)$

Day -1 : Pla

9.5

$39(P<0.05) \quad 3$

Day 1: Dex 20 mg + Ap 400 mg + Pla

Day 2-5: Ap 300 mg

$(n=86)$

\begin{tabular}{|c|c|c|c|c|c|c|}
\hline \multirow[t]{3}{*}{$\begin{array}{l}\text { Cis-based } \\
\geq 70 \mathrm{mg} / \mathrm{m}^{2} \\
1 \text { cycle }\end{array}$} & $\begin{array}{l}\text { Day 1: L-758,298 } 100 \mathrm{mg}+\text { Dex } 20 \mathrm{mg} \\
\text { Day 2-5: Ap } 300 \mathrm{mg} \\
(\mathrm{n}=61)\end{array}$ & 44 & & $59(P<0.005)$ & 5 & $\begin{array}{l}\text { Van Belle et al. } \\
2002\end{array}$ \\
\hline & $\begin{array}{l}\text { Day 1: L-758,298 } 100 \mathrm{mg}+\text { Dex } 20 \mathrm{mg} \\
\text { Day 2-5: Pla } \\
(\mathrm{n}=58)\end{array}$ & 36 & & 46 & 4 & \\
\hline & $\begin{array}{l}\text { Day 1: Ond } 32 \mathrm{mg}+\text { Dex } 20 \mathrm{mg} \\
\text { Day 2-5: Pla } \\
(\mathrm{n}=58)\end{array}$ & $\begin{array}{l}83(P<0.001 \\
\text { vs other two } \\
\text { groups } \\
\text { combined })\end{array}$ & $\begin{array}{l}1(P<0.005 \text { vs } \\
\text { other two groups } \\
\text { combined })\end{array}$ & 38 & 1 & \\
\hline \multirow[t]{3}{*}{$\begin{array}{l}\text { Cis-based } \\
\geq 70 \mathrm{mg} / \mathrm{m}^{2} \\
1 \text { cycle }\end{array}$} & $\begin{array}{l}\text { Day 1: Ap } 125 \mathrm{mg}+\text { Ond } 32 \mathrm{mg}+\text { Dex } 20 \mathrm{mg} \\
\text { Day 2-5: Ap } 80 \mathrm{mg}+\text { Dex } 8 \mathrm{mg} \\
(\mathrm{n}=131)\end{array}$ & $\begin{array}{l}83.2 \\
(P<0.05)\end{array}$ & NR & $72.7(P<0.01)$ & NR & Chawla et al. 2003 \\
\hline & $\begin{array}{l}\text { Day 1: Ap } 40 \mathrm{mg}+\text { Ond } 32 \mathrm{mg}+\text { Dex } 20 \mathrm{mg} \\
\text { Day 2-5: Ap } 25 \mathrm{mg}+\text { Dex } 8 \mathrm{mg} \\
(\mathrm{n}=119)^{\mathrm{b}}\end{array}$ & 75.6 & NR & $63.9(P<0.01)$ & NR & \\
\hline & $\begin{array}{l}\text { Day 1: Ond } 32 \mathrm{mg}+\text { Dex } 20 \mathrm{mg}+\mathrm{Pla} \\
\text { Day 2-5: Dex } 8 \mathrm{mg}+\mathrm{Pla} \\
(\mathrm{n}=126)\end{array}$ & 71.4 & NR & 45.2 & NR & \\
\hline
\end{tabular}




\begin{tabular}{|c|c|c|c|c|c|c|}
\hline \multicolumn{7}{|c|}{...table continued } \\
\hline \multirow{3}{*}{$\begin{array}{l}\text { Chemotherapy } \\
\text { regimen }\end{array}$} & \multirow[t]{3}{*}{ Antiemetic treatment } & \multicolumn{4}{|c|}{ Outcome } & \multirow[t]{3}{*}{ Reference } \\
\hline & & \multicolumn{2}{|c|}{ Acute phase } & \multicolumn{2}{|c|}{ Delayed phase } & \\
\hline & & $\begin{array}{l}\text { Complete } \\
\text { response } \\
(\%)^{\mathrm{a}}\end{array}$ & $\begin{array}{l}\text { Nausea (median } \\
\text { VAS scores; } \\
0=\text { none; } \\
100=\text { worst) }\end{array}$ & $\begin{array}{l}\text { Complete } \\
\text { response }(\%)^{\mathrm{a}}\end{array}$ & $\begin{array}{l}\text { Nausea (median } \\
\text { VAS scores; } \\
0=\text { none; } \\
100=\text { worst) }\end{array}$ & \\
\hline \multirow{4}{*}{$\begin{array}{l}\text { Cis-based } \\
\geq 70 \mathrm{mg} / \mathrm{m}^{2} \\
6 \text { cycles }\end{array}$} & \multirow{2}{*}{$\begin{array}{l}\text { Day 1: Ap } 125 \mathrm{mg}+\text { Ond } 32 \mathrm{mg}+\text { Dex } 20 \mathrm{mg} \\
\text { Day 2-5: Ap } 80 \mathrm{mg}+\text { Dex } 8 \mathrm{mg} \\
(\mathrm{n}=81)^{\mathrm{b}}\end{array}$} & NR & NR & $\begin{array}{l}\text { Cycle 1: } 64 \\
(P<0.05)\end{array}$ & NR & de Wit et al. $2003^{c}$ \\
\hline & & & & $\begin{array}{l}\text { Cycle } 6(n=27) \text { : } \\
59(P<0.05)\end{array}$ & & \\
\hline & Day 1: Ond 32 mg + Dex 20 mg + Pla & NR & NR & Cycle 1: 49 & NR & \\
\hline & $\begin{array}{l}\text { Day 2-5: Dex } 8 \text { mg + Pla } \\
(n=86)\end{array}$ & & & $\begin{array}{l}\text { Cycle } 6(n=33) \text { : } \\
34\end{array}$ & & \\
\hline \multirow{3}{*}{$\begin{array}{l}\text { Cis-based } \\
\geq 70 \mathrm{mg} / \mathrm{m}^{2} \\
1 \text { cycle }\end{array}$} & $\begin{array}{l}\text { Day 1: Ap } 125 \mathrm{mg}+\text { Ond } 32 \mathrm{mg}+\text { Dex } 12 \mathrm{mg} \\
\text { Day 2-3: Ap } 80 \mathrm{mg}+\text { Dex } 8 \mathrm{mg}\end{array}$ & $\begin{array}{l}89.2 \\
(P<0.001)\end{array}$ & $90.6^{d}$ & $75.4(P<0.001)$ & $75.3^{d}$ & Hesketh et al. 2003 \\
\hline & $\begin{array}{l}\text { Day 4: Dex } 8 \mathrm{mg} \\
(\mathrm{n}=260)\end{array}$ & & & & & \\
\hline & $\begin{array}{l}\text { Day 1: Ond } 32 \mathrm{mg}+\text { Dex } 20 \mathrm{mg}+\mathrm{Pla} \\
\text { Day 2-4: Dex } 8 \mathrm{mg} \text { bid + Pla } \\
(\mathrm{n}=261)\end{array}$ & 78.1 & $86.5^{\mathrm{d}}$ & 55.8 & $68.5^{\mathrm{d}}$ & \\
\hline \multirow[t]{2}{*}{$\begin{array}{l}\text { Cis-based } \\
\geq 70 \mathrm{mg} / \mathrm{m}^{2} \\
1 \mathrm{cycle}\end{array}$} & $\begin{array}{l}\text { Day 1: Ap } 125 \mathrm{mg}+\text { Ond } 32 \mathrm{mg} \text { + Dex } 12 \mathrm{mg} \\
\text { Day 2-3: Ap } 80 \mathrm{mg}+\text { Dex } 8 \mathrm{mg} \\
\text { Day 4: Dex } 8 \mathrm{mg} \\
(\mathrm{n}=283)\end{array}$ & $\begin{array}{l}82.8 \\
(P<0.001)\end{array}$ & NR & $67.7(P<0.001)$ & $73^{d}$ & $\begin{array}{l}\text { Poli-Bigelli et al. } \\
2003\end{array}$ \\
\hline & $\begin{array}{l}\text { Day 1: Ond } 32 \mathrm{mg}+\text { Dex } 20 \mathrm{mg}+\mathrm{Pla} \\
\text { Day 2-4: Dex } 8 \mathrm{mg} \text { bid + Pla } \\
(\mathrm{n}=286)\end{array}$ & 68.4 & NR & 46.8 & $65^{d}$ & \\
\hline \multirow{5}{*}{$\begin{array}{l}\text { Cis-based } \\
\geq 70 \mathrm{mg} / \mathrm{m}^{2} \\
6 \text { cycles }\end{array}$} & Day 1: Ap 125 mg + Ond 32 mg + Dex 12 mg & \multirow{3}{*}{\multicolumn{2}{|c|}{$\begin{array}{l}\text { Cycle 1: } 61^{e}(P<0.001) \\
\text { Cycle } 6(n=89): 59^{e}(P<0.001)\end{array}$}} & & & de Wit et al. $2004^{f}$ \\
\hline & Day 2-3: Ap 80 mg + Dex 8 mg & & & & & \\
\hline & $\begin{array}{l}\text { Day 4: Dex } 8 \mathrm{mg} \\
(\mathrm{n}=547)\end{array}$ & & & & & \\
\hline & Day 1: Ond $32 \mathrm{mg}+$ Dex $20 \mathrm{mg}+\mathrm{Pla}$ & \multicolumn{2}{|l|}{ Cycle 1: $46^{e}$} & & & \\
\hline & $\begin{array}{l}\text { Day 2-4: Dex } 8 \text { mg bid + Pla } \\
(n=552)\end{array}$ & \multicolumn{2}{|c|}{ Cycle $6(n=78): 40^{e}$} & & & \\
\hline \multirow[t]{2}{*}{$\begin{array}{l}\text { Cis-based } \\
\geq 70 \mathrm{mg} / \mathrm{m}^{2} \\
+ \text { Cyc }(87) \\
\text { and/or Dox }(74)^{\mathrm{g}}\end{array}$} & $\begin{array}{l}\text { Day 1: Ap } 125 \mathrm{mg}+\text { Ond } 32 \mathrm{mg}+\text { Dex } 12 \mathrm{mg} \\
\text { Day 2-3: Ap } 80 \mathrm{mg}+\text { Dex } 8 \mathrm{mg} \\
\text { Day 4: Dex } 8 \mathrm{mg} \\
(\mathrm{n}=520)\end{array}$ & $71(P<0.005)$ & NR & $67(P<0.005)$ & NR & Gralla et al. $2005^{f}$ \\
\hline & $\begin{array}{l}\text { Day 1: Ond } 32 \mathrm{mg}+\text { Dex } 20 \mathrm{mg}+\mathrm{Pla} \\
\text { Day 2-4: Dex } 8 \mathrm{mg} \text { bid + Pla } \\
(\mathrm{n}=523)\end{array}$ & 49 & NR & 32 & NR & \\
\hline \multirow{3}{*}{$\begin{array}{l}\text { Cis-based } \\
\geq 70 \mathrm{mg} / \mathrm{m}^{2} \\
1 \text { cycle }\end{array}$} & $\begin{array}{l}\text { Day 1: Ap } 125 \mathrm{mg}+\text { Ond } 32 \mathrm{mg}+\text { Dex } 12 \mathrm{mg} \\
\text { Day 2-3: Ap } 80 \mathrm{mg}+\text { Dex } 8 \mathrm{mg}\end{array}$ & $86(P<0.001)$ & $91^{\mathrm{d}}(P<0.01)$ & $72(P<0.001)$ & $74^{\mathrm{d}}(P<0.05)$ & Warr et al. $2005 \mathrm{a}^{\dagger}$ \\
\hline & $\begin{array}{l}\text { Day 4: Dex } 8 \mathrm{mg} \\
(\mathrm{n}=547)\end{array}$ & & & & & \\
\hline & $\begin{array}{l}\text { Day 1: Ond } 32 \mathrm{mg}+\text { Dex } 20 \mathrm{mg}+\mathrm{Pla} \\
\text { Day 2-4: Dex } 8 \mathrm{mg} \text { bid + Pla } \\
(\mathrm{n}=552)\end{array}$ & 73 & $85^{d}$ & 51 & $67^{d}$ & \\
\hline \multirow[t]{2}{*}{$\begin{array}{l}\text { Cis-based } \\
\geq 70 \mathrm{mg} / \mathrm{m}^{2} \\
1 \mathrm{cycle}\end{array}$} & $\begin{array}{l}\text { Day 1: Ap } 125 \mathrm{mg}+\text { Ond } 32 \mathrm{mg}+\text { Dex } 12 \mathrm{mg} \\
\text { Day 2-3: Ap } 80 \mathrm{mg}+\text { Dex } 8 \mathrm{mg} \\
\text { Day 4: Dex } 8 \mathrm{mg} \\
(\mathrm{n}=484 \text { in total) }\end{array}$ & $\begin{array}{l}87.7 \\
(P=0.005)\end{array}$ & NR & $74.1(P=0.004)$ & NR & Schmoll et al. 2006 \\
\hline & $\begin{array}{l}\text { Day 1: Ond } 32 \mathrm{mg}+\text { Dex } 20 \mathrm{mg} \\
\text { Day 2-4: Ond } 8 \mathrm{mg} \text { bid + Dex } 8 \mathrm{mg} \text { bid }\end{array}$ & 79.3 & NR & 63.1 & & NR \\
\hline \multicolumn{7}{|c|}{$\begin{array}{l}\text { aDefined as no vomiting or use of rescue medication; bPatients initially received aprepitant } 375 \mathrm{mg} \text { on day } 1 \text { and } 250 \mathrm{mg} \text { on days } 2-5 \text { but this arm discontinued due to emerging } \\
\text { pharmacokinetic data indicating effect on dexamethasone plasma concentrations; "Extension of Chawla et al. 2003; dPercentage of patients reporting no significant nausea (peak VAS <25); } \\
\text { eResults presented as "full protection" defined as no vomiting and no significant nausea (i.e. interfering with daily activities); 'Pooled analysis of Hesketh et al. } 2003 \text { and Poli-Bigelli et al. } 2003 \text {; } \\
\text { 9Analysis limited to patients receiving these concomitant drugs. Other patients received etoposide, fluorouracil, gemcitabine, vinorelbine, paclitaxel, and docetaxel. }\end{array}$} \\
\hline \multicolumn{7}{|c|}{$\begin{array}{l}\text { Ap, aprepitant; bid, twice daily; CINV, chemotherapy-induced nausea and vomiting; Cis, cisplatin; Cyc, cyclophosphamide; Dex, dexamethasone; Dox, doxorubicin; Gra, granisetron; NR, not } \\
\text { reported; Ond, ondansetron; Pla, placebo; RCT, randomized controlled trial; VAS, visual analog scale. }\end{array}$} \\
\hline
\end{tabular}


These studies, which involved over 1000 patients, corroborate the phase II evidence and demonstrate that addition of aprepitant to a standard antiemetic regimen of a serotonin antagonist plus a corticosteroid results in significantly greater control of emesis, particularly in the delayed phase (Table 4). Ondansetron $32 \mathrm{mg}$ intravenously plus dexamethasone $20 \mathrm{mg}$ orally on day 1 , followed by dexamethasone $8 \mathrm{mg}$ twice daily on days 2 to 4 gave complete response rates of 68 to $78 \%$ in the acute phase, and 47 to $56 \%$ in the delayed phase, which is consistent with previous clinical experience. Adding aprepitant significantly improved acute complete response rates by 11 to $14 \%$ and delayed rates by $20 \%$; overall, from days 1 to 5 , the improvement was 19 to $20 \%$. All patients with no acute emesis were also more likely to be emesis-free in the delayed phase, but delayed emesis was less likely in the acute emesis-free aprepitant recipients compared with those given standard therapy according to both Hesketh et al. (2003) (13.7 vs 30.6\%) and Poli-Bigelli et al. (2003) (20.7 vs $35.4 \%$ ). A subanalysis on the pooled results of these studies reported delayed emesis rates of $68 \%$ in the $13 \%$ of aprepitant recipients experiencing acute emesis, compared with $85 \%$ of $26 \%$ in the control group (Warr et al. 2005a). Similar numbers of patients experienced an emetic episode in the first 12 hours of treatment, and remained relatively consistent in the aprepitant group. Vomiting occurred in approximately 20 patients receiving aprepitant in each 4-hour interval up to 24 hours and 8-hour interval up to 5 days, in contrast to the patients receiving standard therapy, 66 of whom vomited in the 20-24-hour interval, reaching a peak of 80 patients in 40-48 hours (Warr et al. 2005a). A similar pattern was observed for patients who had $>1$ episode of vomiting. However, the number of patients who had $\leq 5$ or $\leq 3$ emetic episodes were similar in both aprepitant and standard therapy groups (65 vs $64 \%$, and 49 vs $47 \%$, respectively).

A number of other subanalyses of the combined results of Hesketh et al. (2003) and Poli-Bigelli et al. (2003) have been published. One provides evidence that the benefits of adding aprepitant are maintained through multiple cycles of chemotherapy (de Wit et al. 2004), with complete response in the sixth cycle in $59 \%$ of the aprepitant group, compared with $40 \%$ for standard therapy (Table 4). Another looked at between-sex differences in response. As mentioned earlier, women are at higher risk of CINV than men, and this finding was also seen with aprepitant, with lower response rates in female patients compared with males (Hesketh et al. 2006a). However, women receiving aprepitant had significantly better response rates than those receiving standard therapy: 86 versus $66 \%$ in the acute phase, and 70 versus $45 \%$ in the delayed phase. A further analysis investigated the efficacy of adding aprepitant in patients receiving moderately emetogenic chemotherapy with cyclophosphamide and/or doxorubicin as well as cisplatin (Gralla et al. 2005). Among this subgroup, complete responses were seen during the acute and delayed phase in 71 and $67 \%$, respectively, of those receiving aprepitant $(n=70)$ compared with 49 and $32 \%$ of those on standard antiemetics $(n=72)$. Overall, the response to aprepitant in this subset was greater than in the total treatment population.
Feelings of nausea were also reduced by aprepitant (Table 4). The combined analysis by Warr et al. (2005a) revealed a significant improvement in favor of aprepitant for both acute and delayed nausea scores. The rates for the combined endpoint of complete protection (no emesis, no rescue antiemetic medication, and no significant nausea defined as a score of $<25 \mathrm{~mm}$ on the VAS) was 55.6 and $63.4 \%$ for aprepitant versus 40.7 and $49.2 \%$ for standard therapy $(P<0.01)$ (Hesketh et al. 2003; Poli-Bigelli et al. 2003).

Administration of a serotonin antagonist on multiple days is recommended in treatment guidelines to control delayed CINV due to moderately, but not highly, emetogenic chemotherapy (Table 3). Nevertheless, one study has compared an aprepitant regimen (aprepitant, ondansetron, and dexamethasone on day 1; aprepitant and dexamethasone on days 2 to 3; and dexamethasone on day 4) with ondansetron and dexamethasone given over 4 days in 484 patients receiving cisplatin $\geq 70 \mathrm{mg} / \mathrm{m}^{2}$ (Schmoll et al. 2006). Complete responses occurred in $88 \%$ of the aprepitant group versus $79 \%$ with ondansetron in the acute phase $(P=0.005)$, and in 74 versus $63 \%(P=0.004)$ in the delayed phase. Aprepitant has also been used as salvage therapy in 29 patients refractory to standard antiemetic therapy, where it decreased the proportion of patients experiencing emesis for $>2$ days from 85 to $0 \%$, and those with nausea for $>4$ days from 77 to $12 \%$, although the frequency of acute nausea occurred in 16 patients (62\%) (Bokemeyer et al. 2005).

Clearly, CINV can have a considerable negative effect on patients' wellbeing and day-to-day functioning. Using the FLIE questionnaire, $74 \%$ of patients taking aprepitant reported minimal or no impact on daily life, approximately $10 \%$ more than those on standard antiemetics (Table 5).

There is limited level 4 evidence from two case reports that aprepitant is effective in adolescent patients receiving highly emetogenic chemotherapy, which is an observation worthy of further study since younger patients are at greater risk of CINV (Smith et al. 2005).

\section{Control of CINV with moderately emetogenic chemotherapy}

As mentioned above, the protective efficacy of aprepitant appears to be greater in patients receiving moderately emetogenic chemotherapy with cyclophosphamide and/or doxorubicin as well as cisplatin, and women responded better than to standard antiemetic treatment. There is also evidence from an abstract that adding aprepitant to a standard regimen of palonosetron and dexamethasone is effective in patients receiving moderately or moderate to highly emetogenic chemotherapy with cyclophosphamide plus doxorubicin, or paclitaxel plus carboplatin (Grote et al. 2004; Table 6).

Consequently, the efficacy of aprepitant in preventing CINV caused by moderately emetogenic regimens has been evaluated in an RCT in 866 patients with breast cancer (all but two were women) receiving cyclophosphamide with or without doxorubicin or epirubicin (Warr et al. 2005b). Aprepitant $125 \mathrm{mg}$ plus 
Table 5 | Level 2 evidence of patient satisfaction with aprepitant in the prevention of CINV in double-blind, mulicenter, parallel-group RCTs

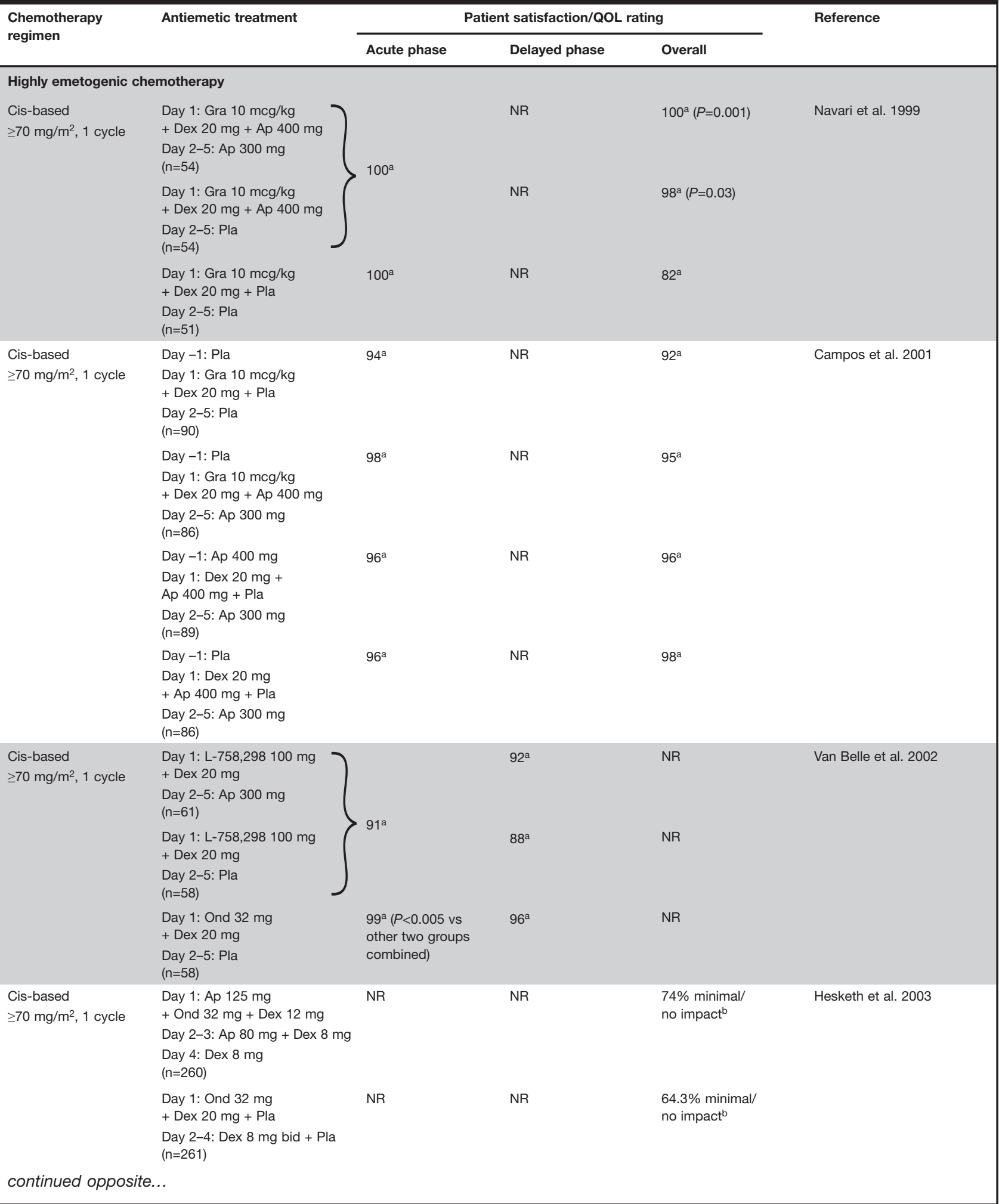




\begin{tabular}{|c|c|c|c|c|c|}
\hline \multicolumn{6}{|l|}{...table continued } \\
\hline \multirow{2}{*}{$\begin{array}{l}\text { Chemotherapy } \\
\text { regimen }\end{array}$} & \multirow[t]{2}{*}{ Antiemetic treatment } & \multicolumn{3}{|c|}{ Patient satisfaction/QOL rating } & \multirow[t]{2}{*}{ Reference } \\
\hline & & Acute phase & Delayed phase & Overall & \\
\hline \multirow[t]{3}{*}{$\begin{array}{l}\text { Cis-based } \\
\geq 70 \mathrm{mg} / \mathrm{m}^{2}, 1 \text { cycle }\end{array}$} & $\begin{array}{l}\text { Day 1: Ap } 125 \mathrm{mg}+ \\
\text { Ond } 32 \mathrm{mg}+\text { Dex } 12 \mathrm{mg} \\
\text { Day 2-3: Ap } 80 \mathrm{mg}+\text { Dex } 8 \mathrm{mg} \\
\text { Day 4: Dex } 8 \mathrm{mg} \\
(\mathrm{n}=283)\end{array}$ & NR & NR & $\begin{array}{l}74.7 \% \text { minimal/ }^{\mathrm{b}} \\
\text { no impact }{ }^{\mathrm{b}}\end{array}$ & Poli-Bigelli et al. 2003 \\
\hline & $\begin{array}{l}\text { Day 1: Ond } 32 \mathrm{mg} \\
+ \text { Dex } 20 \mathrm{mg}+\mathrm{Pla}\end{array}$ & NR & NR & $\begin{array}{l}63.5 \% \text { minimal/ } \\
\text { no impact }{ }^{b}\end{array}$ & \\
\hline & $\begin{array}{l}\text { Day 2-4: Dex } 8 \mathrm{mg} \text { bid + Pla } \\
(\mathrm{n}=286)\end{array}$ & & & & \\
\hline \multirow[t]{3}{*}{$\begin{array}{l}\text { Cis-based } \\
\geq 70 \mathrm{mg} / \mathrm{m}^{2}, 1 \text { cycle }\end{array}$} & $\begin{array}{l}\text { Day 1: Ap } 125 \mathrm{mg}+ \\
\text { Ond } 32 \mathrm{mg}+\text { Dex } 12 \mathrm{mg} \\
\text { Day 2-3: Ap } 80 \mathrm{mg}+\text { Dex } 8 \mathrm{mg} \\
\text { Day 4: Dex } 8 \mathrm{mg} \\
(\mathrm{n}=547)\end{array}$ & NR & NR & $\begin{array}{l}74 \% \text { minimal/ } \\
\text { no impact }{ }^{\mathrm{b}}(P<0.01 \\
\text { vs standard therapy) }\end{array}$ & Warr et al. $2005 \mathrm{a}^{\mathrm{c}}$ \\
\hline & $\begin{array}{l}\text { Day 1: Ond } 32 \mathrm{mg} \\
+ \text { Dex } 20 \mathrm{mg}+\text { Pla }\end{array}$ & $N R$ & NR & $\begin{array}{l}64 \% \text { minimal/ } \\
\text { no impact }{ }^{b}\end{array}$ & \\
\hline & $\begin{array}{l}\text { Day 2-4: Dex } 8 \text { mg bid + Pla } \\
(n=552)\end{array}$ & & & & \\
\hline \multicolumn{6}{|c|}{ Moderately emetogenic chemotherapy } \\
\hline $\begin{array}{l}\text { Cyс } \\
750-1500 \mathrm{mg} / \mathrm{m}^{2} \\
\text { alone or Cyc }\end{array}$ & $\begin{array}{l}\text { Day 1: Ap } 125 \mathrm{mg}+ \\
\text { Ond } 8 \mathrm{mg}+\text { Dex } 12 \mathrm{mg} \text { before } \\
\text { chemo and Ond } 8 \mathrm{mg} \text { after } 8 \mathrm{~h}\end{array}$ & NR & NR & 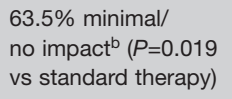 & Warr et al. $2005 \mathrm{~b}$ \\
\hline \multirow{3}{*}{$\begin{array}{l}500-1500 \mathrm{mg} / \mathrm{m}^{2} \\
+ \text { Dox } \leq 60 \mathrm{mg} / \mathrm{m}^{2} \text { or } \\
\text { Epi } \leq 100 \mathrm{mg} / \mathrm{m}^{2} \text {, } \\
4 \text { cycles }\end{array}$} & $\begin{array}{l}\text { Day 2-3: Ap } 80 \mathrm{mg} \\
(\mathrm{n}=438)\end{array}$ & & & & \\
\hline & $\begin{array}{l}\text { Day 1: Ond } 8 \mathrm{mg}+ \\
\text { Dex } 20 \mathrm{mg}+\text { Pla before chemo } \\
\text { and Ond } 8 \mathrm{mg} \text { after } 8 \mathrm{~h}\end{array}$ & NR & NR & $\begin{array}{l}55.6 \% \text { minimal/ } \\
\text { no impact }{ }^{b}\end{array}$ & \\
\hline & $\begin{array}{l}\text { Day 2-3: Ond } 8 \mathrm{mg} \text { bid } \\
(\mathrm{n}=428)\end{array}$ & & & & \\
\hline \multicolumn{6}{|c|}{$\begin{array}{l}\text { aMedian global satisfaction VAS ratings ( } 0=\text { not at all satisfied; } 100=\text { completely satisfied); b }{ }^{\mathrm{F}} \text { unctional Living Index Emesis (FLIE) questionnaire response; }{ }^{\mathrm{c} P o o l e d} \text { analysis of Hesketh et al } \\
2003 \text { and Poli-Bigelli et al. } 2003 .\end{array}$} \\
\hline
\end{tabular}

ondansetron and dexamethasone on day 1 followed by aprepitant $80 \mathrm{mg}$ on days 2 and 3 produced more complete responses than ondansetron plus dexamethasone alone on day 1 followed by the serotonin antagonist on days 2 and 3 (Table 6). The difference between antiemetic treatments was significant for acute CINV, although control of nausea was comparable between groups. This was reflected in the nausea domain in the FLIE assessment, with no difference between groups, although overall significantly more patients receiving aprepitant reported minimal or no impact on daily living ( 63.5 vs $55.6 \% ; P=0.019)$. In those patients who experienced emesis, the time to first episode of vomiting was also delayed by aprepitant.

An extension of this study provides evidence that the protective effect of aprepitant is maintained over multiple cycles (Herrstedt et al. 2005b). Among evaluable patients who had a complete response in cycle 1, response was sustained in cycle 4 in $34.5 \%$ of the aprepitant group and $23.9 \%$ of the standard therapy group (Table 6). The difference was greatest in patients who experienced no emesis, becoming progressively more pronounced by cycle 4 . The frequency of nausea was similar between groups, although more aprepitant recipients reported lack of significant nausea, the difference being significant during cycle 2 (65.5 vs $56.9 \%$; $P=0.02)$.

These positive results are still filtering their way into clinical practice, although current guidelines do reflect the approval of aprepitant for preventing CINV due to moderately emetogenic chemotherapy (see Patient group/population). Many patients on cyclophosphamide plus doxorubicin are still receiving a serotonin antagonist plus dexamethasone. However, as discussed earlier, not all patients respond to this regimen, particularly over 
Table 6 | Outcomes achieved with aprepitant in the prevention of CINV due to moderately emetogenic chemotherapy (all $P$ values vs standard therapy without aprepitant unless otherwise stated)

\begin{tabular}{|c|c|c|c|c|c|c|c|c|}
\hline \multirow{3}{*}{$\begin{array}{l}\text { Level of } \\
\text { evidence }\end{array}$} & \multirow{3}{*}{ Design } & \multirow{3}{*}{$\begin{array}{l}\text { Chemotherapy } \\
\text { regimen }\end{array}$} & \multirow[t]{3}{*}{ Antiemetic treatment } & \multicolumn{4}{|c|}{ Outcome } & \multirow[t]{3}{*}{ Reference } \\
\hline & & & & \multicolumn{2}{|c|}{ Acute phase } & \multicolumn{2}{|c|}{ Delayed phase } & \\
\hline & & & & $\begin{array}{l}\text { Complete } \\
\text { response }(\%)^{\mathrm{a}}\end{array}$ & $\begin{array}{l}\text { Nausea (median } \\
\text { VAS scores; } \\
0=\text { none; } \\
100=\text { worst) }\end{array}$ & $\begin{array}{l}\text { Complete } \\
\text { response }(\%)^{\mathrm{a}}\end{array}$ & $\begin{array}{l}\text { Nausea (median } \\
\text { VAS scores; } \\
0=\text { none; } \\
100=\text { worst) }\end{array}$ & \\
\hline 2 & $\begin{array}{l}\text { DB, } \\
M C, P G\end{array}$ & $\begin{array}{l}\text { Cyc } \\
750-1500 \mathrm{mg} / \mathrm{m}^{2} \\
\text { alone or Cyc } \\
500-1500 \mathrm{mg} / \mathrm{m}^{2} \\
+ \text { Dox } \leq 60 \mathrm{mg} / \mathrm{m}^{2} \\
\text { or Epi } \\
\leq 100 \mathrm{mg} / \mathrm{m}^{2}, \\
4 \text { cycles }\end{array}$ & $\begin{array}{l}\text { Day 1: Ap } 125 \mathrm{mg} \\
+ \text { Ond } 8 \mathrm{mg}+\text { Dex } 12 \mathrm{mg} \\
\text { before chemo and Ond } \\
8 \mathrm{mg} \text { after } 8 \mathrm{~h} \\
\text { Day 2-3: Ap } 80 \mathrm{mg} \\
(\mathrm{n}=438)\end{array}$ & NR & 0 & $\begin{array}{l}\text { Cycle 1: } 50.8 \\
(P=0.017) \\
\text { Cycle } 4(n=344): \\
34.5(P=0.017)\end{array}$ & $\begin{array}{l}\text { Cycle 1: } 60.9^{\mathrm{b}} \\
\text { Cycle } 4(n=344): \\
74.1^{\mathrm{b}}\end{array}$ & $\begin{array}{l}\text { Herrstedt et al. } \\
2005 b^{c}\end{array}$ \\
\hline \multirow[t]{2}{*}{2} & \multirow[t]{2}{*}{$\begin{array}{l}\text { DB, } \\
\text { MC, PG }\end{array}$} & \multirow[t]{2}{*}{$\begin{array}{l}\text { Cyc } \\
750-1500 \mathrm{mg} / \mathrm{m}^{2} \\
\text { alone or Cyc } \\
500-1500 \mathrm{mg} / \mathrm{m}^{2} \\
+ \text { Dox } \leq 60 \mathrm{mg} / \mathrm{m}^{2} \\
\text { or Epi } \\
\leq 100 \mathrm{mg} / \mathrm{m}^{2}, \\
4 \text { cycles }\end{array}$} & $\begin{array}{l}\text { Day 1: Ap } 125 \mathrm{mg} \\
\text { + Ond } 8 \mathrm{mg}+\text { Dex } 12 \mathrm{mg} \\
\text { before chemo and Ond } \\
8 \mathrm{mg} \text { after } 8 \mathrm{~h} \\
\text { Day 2-3: Ap } 80 \mathrm{mg} \\
(\mathrm{n}=438)\end{array}$ & $\begin{array}{l}76(P=0.034 \\
\text { vs Pla })\end{array}$ & NR & 55 & $61^{b}$ & \multirow[t]{2}{*}{ Warr et al. 2005b } \\
\hline & & & $\begin{array}{l}\text { Day 1: Ond } 8 \mathrm{mg} \\
\text { + Dex } 20 \mathrm{mg}+\mathrm{Pla} \\
\text { before chemo and } \\
\text { Ond } 8 \mathrm{mg} \text { after } 8 \mathrm{~h} \\
\text { Day 2-3: Ond } 8 \mathrm{mg} \text { bid } \\
(\mathrm{n}=428)\end{array}$ & 69 & NR & 49 & $56^{\mathrm{b}}$ & \\
\hline \multirow[t]{2}{*}{3} & \multirow[t]{2}{*}{$\mathrm{MC}$} & \multirow[t]{2}{*}{$\begin{array}{l}\text { Dox } \leq 60 \mathrm{mg} / \mathrm{m}^{2}+ \\
\text { Cyc } \geq 500 \mathrm{mg} / \mathrm{m}^{2}, \\
2 \text { cycles }\end{array}$} & $\begin{array}{l}\text { Day 1: Ond } 8 \text { mg, } \\
\text { Dol } 100 \mathrm{mg} \text {, or Gra } 1 \text { or } \\
2 \mathrm{mg}+\text { Dex } 8-10 \mathrm{mg} \\
\text { Day 2-3: Dex } 4 \mathrm{mg} \text { bid } \\
(\mathrm{n}=34 \text {; cycle } 1)\end{array}$ & 32 & $0^{j}$ & 12 & $12^{\mathrm{j}}$ & $\begin{array}{l}\text { Hesketh et al. } \\
2006 \mathrm{~b}\end{array}$ \\
\hline & & & $\begin{array}{l}\text { Day 1: Ond } 8 \text { mg, Dol } \\
100 \text { mg, or Gra } 1 \text { or } \\
2 \text { mg + Dex } 8-10 \text { mg } \\
+ \text { Ap } 125 \mathrm{mg} \\
\text { Day 2-3: Dex } 4 \text { mg qd } \\
+ \text { Ap } 80 \mathrm{mg} \\
(n=34 ; \text { cycle } 2)^{d}\end{array}$ & $\begin{array}{l}68(P=0.01 \text { vs } \\
\text { cycle } 1)\end{array}$ & $21^{e}$ & $\begin{array}{l}44(P=0.02 \text { vs } \\
\text { cycle } 1)\end{array}$ & $3^{e}$ & \\
\hline
\end{tabular}


multiple cycles. A phase II trial has investigated the use of a prepitant as salvage therapy in patients receiving chemotherapy with cyclophosphamide plus doxorubicin and refractory to conventional antiemetic treatment with ondansetron plus dexamethasone (Hesketh et al. 2006b). Thirty-four of 42 patients (81\%) did not achieve complete control (no emesis, no nausea, and no rescue medications) to standard therapy in cycle 1 and received additional aprepitant in cycle 2 . Overall, seven patients (21\%) had complete control of their CINV with aprepitant, with complete responses in 23 patients $(68 \%)$ during the acute phase and in 15 (44\%) during the delayed phase (Table 6). Fewer patients reported symptoms of delayed nausea with aprepitant, although more experienced acute nausea.

\section{Tolerability}

At least one adverse event occurred in $69 \%$ of 544 patients receiving aprepitant to control CINV with highly emetogenic chemotherapy, the most frequent being asthenia/fatigue (18\%), nausea $(13 \%$, considered to be drug-related if it occurred after day $5)$, hiccups (11\%), anorexia (10\%), constipation (10\%), and diarrhea (10\%) (Warr et al. 2005a). Infections occurred in $12.5 \%$ of patients, and $11.6 \%$ had a hematologic or lymphatic system adverse event. The incidence of adverse events was similar to that with standard therapy (Hesketh et al. 2003; Poli-Bigelli et al. 2003). During multiple cycles, $6 \%$ of patients had an adverse event related to aprepitant, $19 \%$ had serious clinical adverse events, and $12 \%$ discontinued treatment, a comparable pattern to that seen with standard antiemetic treatment (de Wit et al. 2004).

In patients receiving aprepitant as protection against CINV caused by moderately emetogenic chemotherapy, $21.5 \%$ experienced a drug-related adverse event, considered serious in $3.4 \%$ and necessitating discontinuation in 1.6\% (Warr et al. 2005b). The corresponding rates for standard therapy were 19.6, 4.2, and 1.2\%. There appeared to be slightly more dyspepsia in the aprepitant group ( 8.4 vs $4.9 \%$ ), and less constipation (12.3 vs $18 \%$ ). During repeated administration of aprepitant over two to four cycles, fatigue (20.8\%), alopecia (12.7\%), constipation (9.9\%), and headache (9.4\%) were the most common adverse events (Herrstedt et al. 2005b). Neutropenia was more frequent in the aprepitant group compared with standard therapy ( 9.1 vs $5.8 \%)$, as was grade 3-4 neutropenia (7 vs 3.6\%), possibly as a result of greater exposure to chemotherapy in the aprepitant group, although the difference did not reach significance. Indeed, overall rates of febrile neutropenia (2.9 vs $2.2 \%$ ) and infection (17.1 vs $16.7 \%$ ) were similar.

Aprepitant is metabolized by cytochrome P450 (CYP) 3A4 in the liver, and thus there is the potential for interactions with other agents metabolized by this enzyme. The evidence for clinically relevant interactions is contradictory. One study found a greater incidence of serious adverse events in patients receiving aprepitant and the CYP3A4-metabolized etoposide, vinca alkaloids, and taxanes, compared with those on standard antiemetic therapy (16 vs $8.5 \%$ ) (Poli-Bigelli et al. 2003). In contrast, however, no significant difference in adverse event profile was detected in aprepitant recipients compared with standard therapy in patients who received chemotherapy with the
CYP3A4-metabolized drugs etoposide, vinorelbine, and paclitaxel (Hesketh et al. 2003). Similarly, in a study in patients receiving moderately emetogenic chemotherapy, no adverse events could be attributed to interactions with aprepitant (Warr et al. 2005b). However, caution should still be exercised and some drugs are contraindicated due to the interaction potential of aprepitant (see Dosage, administration, and formulations, below).

\section{Economic evidence}

Available evidence specifically analyzing the cost effectiveness of aprepitant is limited to two abstracts. One study describes a Markov model that compared the then-standard ASCO antiemetic therapy of a serotonin antagonist plus a corticosteroid, with aprepitant plus standard therapy, or aprepitant added to a standard therapy only after CINV occurs (Moore et al. 2005). The model took a payer perspective, and included costs for resource use for CINV management, Medicare reimbursement for hospital and physician services, and average wholesale drug prices. Using clinical trial data to model outcomes, the cost-effectiveness ratios for each of the three regimens was \$US13 907, \$US41 060, and \$US27 619 per quality-adjusted life year (QALY), respectively. Incremental cost-effectiveness ratios compared with standard therapy alone were \$US172789 for aprepitant plus a corticosteroid, and \$US160 236 for adding aprepitant after CINV. Aprepitant became cost effective at a cost of \$US94 when added to standard therapy in this model. The average wholesale price for a course of aprepitant $125 \mathrm{mg}$ on day 1 and $80 \mathrm{mg}$ on days 2 and 3 is \$US312 (Massaro \& Lenz 2005). A decision analysis model looking at $\mathrm{NK}_{1}$ receptor antagonists as a class, rather than aprepitant specifically, estimated that to remain within a target incremental cost-effectiveness threshold of \$Can20000 per QALY, the acquisition cost would have to be $\$$ Can6.60 (range \$Can4.80-10.00) per dose when added to granisetron and dexamethasone after cisplatin-based chemotherapy (Dranitsaris \& Leung 2004). Assuming a regimen of $\mathrm{NK}_{1}$ antagonist being given twice daily for 5 days, the total cost of a course would be $\$ C a n 66.00$ (range \$Can48.00-100.00). Clinical data for the model were taken from a trial of the $\mathrm{NK}_{1}$ receptor antagonist $\mathrm{CJ}-11,974$.

A cost-consequence study found that the costs of an aprepitantcontaining regimen were \$US536154 compared with \$US238 982 for standard antiemetic therapy in a hypothetical cohort of 1000 patients receiving a single cycle of highly emetogenic chemotherapy (Bell et al. 2004). However, over the course of 7 days after chemotherapy, total medical costs were \$US282 948 versus \$US457272, reflecting the greater efficacy of aprepitant.

These cost-effectiveness analyses, while giving an insight into the economic consequences from a payer perspective, nevertheless overlook patients' willingness to pay for an improved quality of life and relief from a distressing side effect of chemotherapy. This aspect has been investigated for $\mathrm{NK}_{1}$ receptor antagonists as a class. Patients from Spain, Canada, Italy, and Greece said they would pay a maximum of \$US63, \$US46, \$US34, and \$US8 per day (in 2000 \$US), respectively, for a $20 \%$ reduction in acute emesis (Dranitsaris et al. 2001a). The corresponding values 
placed on a decrease in delayed emesis of $30 \%$ were $\$$ US50, \$US41, \$US31, and \$US9 per day for 4 days.

\section{Resource utilization}

Costs associated with the management of CINV are significant. A Canadian study involving 92 patients receiving antiemetic prophylaxis with dexamethasone plus metoclopramide and other antiemetics excluding serotonin antagonists, most of whom $(66 \%)$ were on moderately emetogenic chemotherapy, found that additional nursing time and hospital admission represented the largest single extra cost components, at \$Can16.50 and $\$$ Can24.90 per patient, respectively (O'Brien et al. 1993). These costs were mainly from 72 patients who experienced CINV: $\$$ Can17.80 (42 hours of nursing time) and \$Can31.90 (9 hospital days) per patient, with a total additional cost per patient of $\$$ Can63.00. Importantly, indirect costs of CINV were \$Can184.30 per patient, mainly through lost productivity.

Similar results have been reported in Europe, with healthcare resources (mainly rescue medication and physician and hospital visits) used by 68 of 188 patients receiving 208 cycles of moderate to highly emetogenic chemotherapy (Ihbe-Heffinger et al. 2004). CINV occurred in 134 cycles, with the components of direct cost incurred by third party payers (in 2002 currency, per cycle per patient) being medication to prevent CINV (€45.37), treat CINV (€11.20), hospitalization due to CINV (€5.34), physician visits due to CINV (€4.65), and ambulance transport (€3.04). Other direct costs borne by each patient per cycle amounted to $€ 4.64$, and included other-the-counter medications, transport, and childcare; indirect costs through loss of productivity were $€ 3.05$. Across all 208 cycles, corresponding direct costs of treating and preventing CINV per patient per cycle were €48.66, €2.99 for other direct costs, and $€ 1.97$ in indirect costs.

From the perspective of a US office-based oncologist, treatment of an episode of CINV was estimated to incur \$US175 in labor costs (adjusted to 2005 \$US), with an average reimbursement of approximately $\$$ US198, based on the Centers for Medicare and Medicaid Services 2005 reimbursement system (Vanscoy et al. 2005). This difference of $\$$ US23 represents net revenue for a practice, but does not include costs associated with rent or other overheads, indicating the potential economic impact of an uncontrolled episode of CINV at this level.

The costs attributed to treating CINV could potentially be offset by improved prophylaxis. This has been demonstrated for ondansetron, where the higher incremental cost associated with its use was offset by savings in nursing and pharmacy time, hospital stay, and costs of supplies (Stewart et al. 1999). It may be expected that the efficacy of aprepitant may similarly translate into improved resource utilization. The economic evidence for aprepitant gives an insight into its potential cost effectiveness that takes into account costs of treating CINV, resource utilization, and Medicare costs. A cost-consequence study that included costs for aprepitant plus standard antiemetics for a hypothetical group of 1000 patients receiving a single cycle of highly emetogenic chemotherapy concluded that savings in overall direct medical costs would offset $58.7 \%$ (range $20-80 \%$ ) of the incremental cost of adding aprepitant (Bell et al. 2004). Further cost savings could possibly be realized by changing chemotherapy regimens (e.g. giving shorter, more intensive cycles), as this has been demonstrated for ondansetron (Stewart et al. 1999).

\section{Patient group/population}

Aprepitant (Emend) is approved for use with other antiemetic drugs to prevent CINV in patients receiving initial and multiple cycles of highly and moderately emetogenic chemotherapy (Anon. 2006), based on the evidence from RCTs. Aprepitant is established in ASCO, ESMO, Multinational Association for Supportive Care in Cancer (MASCC), and NCCN guidelines for patients on highly emetogenic chemotherapy, and in ASCO, MASCC, and NCCN guidelines for those on an anthracycline plus cyclophosphamide (Table 3). These recommendations will have to be actively implemented in the clinic using pharmacist intervention and education of physicians, as compliance with evidence-based guidelines in the prevention of CINV is often inconsistent (Italian Group for Antiemetic Research 1998; Dranitsaris et al. 2001b).

Aprepitant appears to be particularly useful in preventing delayed CINV, and in women, who are at higher risk of CINV. Aprepitant has been shown to be effective in small numbers of adolescents receiving highly emetogenic chemotherapy, but this requires confirmation in larger studies or groups of patients.

\section{Dosage, administration, and formulations}

The recommended dosage of aprepitant is $125 \mathrm{mg}$ orally 1 hour before chemotherapy on day 1 , followed by $80 \mathrm{mg}$ orally once daily in the morning on days 2 and 3 (Anon. 2006). The drug is available in a combination pack containing one $125 \mathrm{mg}$ and two $80 \mathrm{mg}$ capsules. Dosage adjustment is not necessary in patients with mild to moderate hepatic insufficiency, impaired renal function, or the elderly.

Because it acts as an inhibitor and inducer of CYP3A4, aprepitant should not be taken by patients receiving pimozide, cisapride, terfenadine, and astemizole, and women of child-bearing age taking oral contraceptives containing ethinyl estradiol and norethindrone should use alternative methods of contraception during and 1 month after treatment with aprepitant. Patients taking warfarin should have international normalized ratio of prothrombin time monitored for 2 weeks following aprepitant treatment. The dosage of dexamethasone and oral methylprednisolone as concomitant antiemetic therapy needs to be reduced by approximately $50 \%$ with aprepitant, and that of intravenous methylprednisolone by approximately $25 \%$. Aprepitant may also reduce the plasma concentrations of phenytoin, and increase concentrations of the benzodiazepines midazolam, alprazolam, and triazolam. Caution is also advised when giving concomitant inhibitors of CYP3A4 (such as ketoconazole, itraconazole, clarithromycin, ritonavir, and nelfinavir) which may increase aprepitant concentrations, and with inducers of CYP3A4 (such as rifampin, carbamazepine, and phenytoin) which may reduce its concentration. 


\section{Place in therapy}

CINV presents a considerable burden on patients receiving chemotherapy and on healthcare systems in terms of additional costs. Despite the introduction of the serotonin receptor antagonists and their adoption in clinical guidelines, CINV remains poorly controlled in a significant number of patients, particularly delayed symptoms caused by highly emetogenic drugs, notably cisplatin. Part of this problem stems from poor compliance with guidelines, but the efficacy of existing treatments is also an issue. Furthermore, some moderately emetogenic chemotherapy regimens are actually more likely to cause CINV, and some particular patient groups are at higher risk. Perhaps the best example is the use of adjuvant anthracyclines plus cyclophosphamide in women with breast cancer.

Aprepitant is the first $\mathrm{NK}_{1}$ receptor antagonist to be approved for use in combination with other antiemetics to prevent CINV caused by highly and moderately emetogenic chemotherapy. It has established its place in therapy in highly emetogenic regimens, as it has been integrated into the practice guidelines of ASCO, ESMO, MASCC, and NCCN (Table 3). The evidence for its utility in moderate-risk chemotherapy is also being translated into practice, with its recommendation for use by MASCC and NCCN in patients receiving anthracyclines and cyclophosphamide. As mentioned earlier, these evidence-based clinical guidelines will need to be actively promoted to ensure compliance and recognize the clinical benefits of the drug. There is evidence that a substantial proportion of the acquisition cost of aprepitant can be offset by savings in the overall management of CINV. Furthermore, the evidence gained with the serotonin antagonists indicate that, when properly managed and utilized, advances in antiemetic prophylaxis can save costs in healthcare systems.

The final point that should be made regarding the place of aprepitant is the effect on patient wellbeing. The evidence shows a decrease in episodes of vomiting, use of rescue medication, and feelings of nausea when aprepitant is added to standard antiemetic regimens. This efficacy translates into improved patient satisfaction, which is a key consideration in the overall management of patients with cancer.

In summary, aprepitant adds to the clinician's ability to effectively prevent CINV in a greater proportion of patients receiving chemotherapy with moderate or high emetogenic potential.

\section{References}

Aguilar EA, Figueiras MC, Cortes-Funes $\mathrm{H}$, et al. Clinical practice guidelines on antiemetics in oncology. Expert Rev Anticancer Ther. 2005;5:963-972.

Anon. Emend Prescribing Information. Available at:

http://www.emend.com/aprepitant/emend/hcp/index.jsp (accessed July 31, 2006).

Bell CF, Foley KA, Pelissier JM, Hu HX, Markson LE, Berger ML. Cost consequence model: assessing the use of aprepitant vs. standard anti-emetic therapy in cancer patients undergoing highly emetogenic chemotherapy. Support Care Cancer. 2004;12. Abstract 17.

Bender CM, McDaniel RW, Murphy-Ende K, et al. Chemotherapy-induced nausea and vomiting. Clin J Oncol Nurs. 2002;6:94-102.
Blum RA, Majumdar A, McCrea J, et al. Effects of aprepitant on the pharmacokinetics of ondansetron and granisetron in healthy subjects. Clin Ther. 2003;25:1407-1419.

Bokemeyer C, Oechsle K, Mueller MR, Hartmann JT, Kanz L. Aprepitant as salvage therapy in patients (pts) with chemotherapy (ctx)- induced nausea and emesis $(n / v)$ refractory to prophylaxis with 5-HT3-antagonists and dexamethasone (dexa). J Clin Oncol. 2005;23(Suppl.). Abstract 8166.

Campos D, Pereira JR, Reinhardt RR, et al. Prevention of cisplatin-induced emesis by the oral neurokinin-1 antagonist, MK-869, in combination with granisetron and dexamethasone or with dexamethasone alone. $\mathrm{J}$ Clin Oncol. 2001;19:1759-1767.

CCOHTA (Canadian Coordinating Office for Health Technology Assessment). Aprepitant for nausea from chemotherapy. Emerging Drug List. 2003;50. Available at: http://www.ccohta.ca (accessed July 11, 2006).

Chawla SP, Grunberg SM, Gralla RJ, et al. Establishing the dose of the oral NK1 antagonist aprepitant for the prevention of chemotherapy-induced nausea and vomiting. Cancer. 2003;97:2290-2300.

de Wit R, Herrstedt J, Rapoport B, et al. Addition of the oral NK1 antagonist aprepitant to standard antiemetics provides protection against nausea and vomiting during multiple cycles of cisplatin-based chemotherapy. J Clin Oncol. 2003;21:4105-4111.

de Wit R, Herrstedt J, Rapoport B, et al. The oral NK(1) antagonist, aprepitant, given with standard antiemetics provides protection against nausea and vomiting over multiple cycles of cisplatin-based chemotherapy: a combined analysis of two randomised, placebo-controlled phase III clinical trials. Eur J Cancer. 2004;40:403-410.

Dranitsaris G, Leung P. Using decision modeling to determine pricing of new pharmaceuticals: the case of neurokinin-1 receptor antagonist antiemetics for cancer chemotherapy. Int J Technol Assess Health Care. 2004;20:289-295. Dranitsaris G, Leung P, Ciotti R, et al. A multinational study to measure the value that patients with cancer place on improved emesis control following cisplatin chemotherapy. Pharmacoeconomics. 2001a;19:955-967.

Dranitsaris G, Leung P, Warr D. Implementing evidence based antiemetic guidelines in the oncology setting: results of a 4-month prospective intervention study. Support Cancer Care. 2001b;9:611-618.

Gralla RJ, Osoba D, Kris MG, et al. Recommendations for the use of antiemetics: evidence-based, clinical practice guidelines. J Clin Oncol. 1999;17:2971-2994.

Gralla RJ, de Wit R, Herrstedt J, et al. Antiemetic efficacy of the neurokinin-1 antagonist, aprepitant, plus a $5 \mathrm{HT}_{3}$ antagonist and a corticosteroid in patients receiving anthracyclines or cyclophosphamide in addition to high-dose cisplatin: analysis of combined data from two phase III randomized clinical trials. Cancer. 2005;104:864-868.

Grote T, Hajdenberg J, Cartmell A, et al. Palonosetron (PALO) plus aprepitant (APREP) and dexamethasone (DEX) for the prevention of chemotherapyinduced nausea and vomiting (CINV) after emetogenic chemotherapy (CT). J Clin Oncol. 2004;22(Suppl.). Abstract 8262.

Grunberg SM, Osoba D, Hesketh PJ, et al. Evaluation of new antiemetic agents and definition of antineoplastic agent emetogenicity - an update. Support Care Cancer. 2005;13:80-84.

Herrstedt J, Aapro MS, Roila F, Kataja VV; European Society for Medical Oncology. ESMO minimum clinical recommendations for prophylaxis of chemotherapy-induced nausea and vomiting (NV). Ann Oncol. 2005a;16(Suppl. 1):i77-i79.

Herrstedt J, Muss HB, Warr DG, et al; Aprepitant Moderately Emetogenic Chemotherapy Study Group. Efficacy and tolerability of aprepitant for the prevention of chemotherapy-induced nausea and emesis over multiple cycles of moderately emetogenic chemotherapy. Cancer. 2005b;104:1548-1555. Hesketh PJ, Grunberg SM, Gralla RJ, et al. The oral neurokinin-1 antagonist aprepitant for the prevention of chemotherapy-induced nausea and vomiting: a multinational, randomized, double-blind, placebo-controlled trial in patients receiving high-dose cisplatin - the Aprepitant Protocol 052 Study Group. $J$ Clin Oncol. 2003;21:4112-4119.

Hesketh PJ, Grunberg SM, Herrstedt J, et al. Combined data from two phase III trials of the NK1 antagonist aprepitant plus a 5HT 3 antagonist and a corticosteroid for prevention of chemotherapy-induced nausea and vomiting: effect of gender on treatment response. Support Care Cancer. 2006a;14:354-360. 
Hesketh PJ, Younger J, Sanjay R, et al. Aprepitant as salvage antiemetic therapy in breast cancer patients receiving doxorubicin and cyclophosphamide (AC). J Clin Oncol. 2006;24(Suppl.). Abstract 8618.

Holdsworth MT, Vo-Nguyen T. Employment of substandard antiemetic prophylaxis in recent trials of chemotherapy-induced nausea and vomiting. Ann Pharmacother. 2005;39:1903-1910.

Ihbe-Heffinger A, Ehlken B, Bernard R, et al. The impact of delayed chemotherapy-induced nausea and vomiting on patients, health resource utilization and costs in German cancer centers. Ann Oncol. 2004;15:526-536.

Italian Group for Antiemetic Research. Transferability to clinical practice of the results of controlled clinical trials: the case of antiemetic prophylactic treatment for cancer chemotherapy-induced nausea and vomiting. Ann Oncol. 1998;9:759-765.

Kris MG, Hesketh PJ, Herrstedt J, et al. Consensus proposals for the prevention of acute and delayed vomiting and nausea following high-emeticrisk chemotherapy. Support Care Cancer. 2005;13:85-96.

Kris MG, Hesketh PJ, Somerfield MR, et al. Amercican Society of Clinical Oncology guideline for antiemetics in oncology: update 2006. $\mathrm{J}$ Clin Oncol. 2006;24:2932-2947.

Markman M. Progress in preventing chemotherapy-induced nausea and vomiting. Cleve Clin J Med. 2002;69:609-610, 612, 615-617.

MASCC (Multinational Association for Supportive Care in Cancer). Antiemetic guideline consensus. September 1, 2005. Available at:

http://www.mascc.org/media/Resource_centers/MASCC_Guidelines_Update_9 _05.pdf (accessed July 6, 2006).

Massaro AM, Lenz KL. Aprepitant: a novel antiemetic for chemotherapyinduced nausea and vomiting. Ann Pharmacother. 2005;39:77-85.

Mertens WC, Higby DJ, Brown D, et al. Improving the care of patients with regard to chemotherapy-induced nausea and emesis: the effect of feedback to clinicians on adherence to antiemetic prescribing guidelines. $\mathrm{J}$ Clin Oncol. 2003;21:1373-1378.

Moore SG, Tumeh JW, Wojtanowski S, Flowers CR. Assessing the costeffectiveness of adding aprepitant to the ASCO standard for prophylaxis of chemotherapy induced nausea and vomiting. J Clin Oncol. 2005;23(Suppl.). Abstract 6009.

Navari RM, Reinhardt RR, Gralla RJ, et al. Reduction of cisplatin-induced emesis by a selective neurokinin-1-receptor antagonist. L-754,030 Antiemetic Trials Group. N Engl J Med. 1999;340:190-195.

NCCN (National Comprehensive Cancer Network). Clinical practice guidelines in oncology. Antiemesis. v.2.2006. Available at:

http://www.nccn.org/professionals/physician_gls/PDF/antiemesis.pdf (accessed July 6, 2006).

O'Brien BJ, Rusthoven J, Rocchi A, et al. Impact of chemotherapy-associated nausea and vomiting on patients' functional status and on costs: survey of five Canadian centres. CMAJ. 1993;149:296-302.

Poli-Bigelli S, Rodrigues-Pereira J, Carides AD, et al; Aprepitant Protocol 054 Study Group. Addition of the neurokinin 1 receptor antagonist aprepitant to standard antiemetic therapy improves control of chemotherapy-induced nausea and vomiting. Results from a randomized, double-blind, placebo-controlled trial in Latin America. Cancer. 2003;97:3090-3098.
Schmoll HJ, Aapro MS, Poli-Bigelli S, et al. Comparison of an aprepitant regimen with a multiple-day ondansetron regimen, both with dexamethasone, for antiemetic efficacy in high-dose cisplatin treatment. Ann Oncol. 2006;17:1000-1006.

Sigsgaard T, Herrstedt J, Andersen LJ, et al. Granisetron compared with prednisolone plus metopimazine as anti-emetic prophylaxis during multiple cycles of moderately emetogenic chemotherapy. Br J Cancer. 1999;80:412-418.

Sigsgaard T, Herrstedt J, Handberg J, Kjær M, Dombernowsky P. Ondansetron plus metopimazine compared with ondansetron plus metopimazine plus prednisolone as antiemetic prophylaxis in patients receiving multiple cycles of moderately emetogenic chemotherapy. J Clin Oncol. 2001;19:2091-2097.

Smith AR, Repka TL, Weigel BJ. Aprepitant for the control of chemotherapy induced nausea and vomiting in adolescents. Pediatr Blood Cancer. 2005;45:857-860.

Soukop M, McQuade B, Hunter E, et al. Ondansetron compared with metoclopramide in the control of emesis and quality of life during repeated chemotherapy for breast cancer. Oncology. 1992;49:295-304.

Stewart DJ, Dahrouge S, Coyle D, Evans WK. Costs of treating and preventing nausea and vomiting in patients receiving chemotherapy. $\mathrm{J}$ Clin Oncol. 1999;17:344-351.

Tremont-Lukats IW, González-Barbeteo J, Bruera E, Brescia FJ. Meta-analysis of neurokinin-1 receptor antagonists (NK-1 RA) for chemotherapy-induced nausea and vomiting (CINV). J Clin Oncol. 2004;22:740s. Abstract 8047.

Van Belle S, Lichinitser MR, Navari RM, et al. Prevention of cisplatin-induced acute and delayed emesis by the selective neurokinin-1 antagonists, L-758,298 and MK-869. Cancer. 2002;94:3032-3041.

Vanscoy GJ, Fortner B, Smith R, Weber R, Rihn TL. Preventing chemotherapyinduced nausea and vomiting: the economic implications of choosing antiemetics. Community Oncol. 2005;2:127-132.

Viale $\mathrm{PH}$. Integrating aprepitant and palonosetron into clinical practice: a role for the new antiemetics. Clin J Oncol Nurs. 2005;9:77-84.

Warr DG, Grunberg SM, Gralla RJ, et al. The oral NK(1) antagonist aprepitant for the prevention of acute and delayed chemotherapy-induced nausea and vomiting: pooled data from 2 randomised, double-blind, placebo controlled trials. Eur J Cancer. 2005a;41:1278-1285.

Warr DG, Hesketh PJ, Gralla RJ, et al. Efficacy and tolerability of aprepitant for the prevention of chemotherapy-induced nausea and vomiting in patients with breast cancer after moderately emetogenic chemotherapy. J Clin Oncol. 2005b;23:2822-2830.

Correspondence: Paul Chrisp, Core Medical Publishing, Mere House, Brook Street, Knutsford, Cheshire WA16 8GP, UK or at editor@coreevidence.com 